\title{
DETERMINAN PEMANFAATAN BUKU KESEHATAN IBU DAN ANAK (KIA) OLEH IBU HAMIL DI PUSKESMAS WANAKERTA KABUPATEN KARAWANG TAHUN 2015
}

\section{THE DETERMINANTS OF THE MCH HANDBOOK UTILIZATION BY PREGNANT WOMEN AT WANAKERTA HEALTH CENTER OF KARAWANG REGENCY IN 2015}

\author{
Nita Farida ${ }^{1^{*}}$ \\ ${ }^{I}$ Sekolah Tinggi Ilmu Kesehatan Kharisma, Jln. Pangkal Perjuangan Km. 1 By.Pass Karawang, 41316 Karawang. Indonesia
}

\begin{tabular}{l}
\hline Informasi Artikel: \\
Diterima: maret 2016 \\
Disetujui: Oktober 2016 \\
Kata kunci: \\
Birth pain, nyeri \\
persalinan, pijat endorfin, \\
skala nyeri, kala I fase \\
aktif
\end{tabular}

Key Words

Endorphin massage therapy, pain scale, active phase of the first stage of labor

\begin{abstract}
ABSTRAK
Buku KIA diharapkan dapat meningkatkan partisipasi masyarakat dalam mengontrol kesehatan ibu. Hasil capaian cakupan buku KIA sampai bulan Desember 2014 dari Dinkes Karawang menunjukkan bahwa cakupan Buku KIA yang sebesar 63,49\% dan cakupan K1 yang sebesar 93,37\% menunjukkan perbedaan yang seharusnya adalah sama karena buku KIA diberikan pertama kali saat ibu periksa hamil. Penelitian ini bertujuan untuk memperoleh gambaran pemanfaatan Buku KIA oleh ibu hamil dan faktor-faktor yang berhubungan dengan pemanfaatan Buku KIA pada ibu hamil di wilayah kerja Puskesmas Wanakerta, Kabupaten Karawang tahun 2015. Rancangan penelitian ini adalah Cross Sectional. Populasi pada penelitian ini adalah ibu hamil yang memeriksakan kehamilannya ke Puskesmas Wanakerta dan sampelnya adalah sebagian ibu hamil yang sudah mempunyai buku KIA, dan datang memeriksakan kehamilannya di Puskesmas Wanakerta pada bulan Juni 2015. Hasil penelitian ini menunjukkan bahwa variabel yang berhubungan dengan pemanfaatan buku KIA dalam penelitian ini adalah pendidikan, sikap, dukungan tenaga kesehatan, dukungan kader kesehatan, dan dukungan keluarga. Sementara itu, umur, paritas, dan sosial ekonomi tidak berhubungan dengan pemanfaatan buku KIA oleh ibu hamil.
\end{abstract}




\section{PENDAHULUAN}

Indikator derajat kesehatan masyarakat berhubungan erat dengan Angka Kematian Ibu (AKI) dan Angka Kematian Bayi (AKB). Menurut SDKI 2012, AKI di Indonesia adalah 359 per 100.000 Kelahiran Hidup. Target AKI secara nasional pada tahun 2015 adalah 102 per 100.000 kelahiran hidup sebagai bentuk komitmen yang dibangun dari Millenium Development Goals/MDGs (Kemenkes RI, 2012).

Pada survei pendahuluan, buku KIA telah didistribusikan pada seluruh Puskesmas yang ada diwilayah Kabupaten Karawang (50 Puskesmas), tetapi hasil cakupan buku KIA di Puskesmas Wanakerta masih di bawah cakupan kunjungan ibu hamil pertama kali (K1). Hasil capaian cakupan buku KIA sampai bulan Desember 2014 adalah sebesar 63,49\% dan cakupan K1 adalah sebesar 93,37\%. Pada dasarnya, cakupan buku KIA dan cakupan K1 seharusnya adalah sama, karena buku KIA diberikan pertama kali saat ibu periksa hamil (Dinkes Karawang, 2014). Walaupun demikian, menurut fenomena yang terjadi di masyarakat, pemeriksaan kehamilan yang pertama ini (K1) hanya dilakukan untuk mengecek apakah positif hamil atau tidak, formalitas cek keadaan janin dan menganggap bahwa Buku KIA hanya buku Bidan yang harus dibawa sewaktu pemeriksaan karena bidan akan mencatat hasil pemeriksaan dalam buku tersebut.
Akan tetapi, pada kenyataanya mereka tidak paham bahwa buku KIA adalah buku pegangan ibu. Hal ini dibuktikan dengan tingginya angka kejadian IUFD dan kematian ibu di RSUD Karawang karena keterlambatan dari deteksi dini komplikasi. Selain itu, dari hasil pengamatan yang dilakukan oleh peneliti, materi penyuluhan yang termuat dalam buku KIA belum dijadikan acuan baku dalam penyuluhan. Berdasarkan hasil wawancara peneliti dengan ibu hamil di puskesmas yang berbeda, penyuluhan tidak diberikan secara rinci karena ibu-ibu disuruh membacanya sendiri di rumah, kecuali jika terdapat informasi yang tidak dimengerti, para ibu boleh bertanya pada petugas KIA saat kunjungan.

\section{METODE}

Penelitian ini menggunakan rancangan Cross Sectional. Populasi pada penelitian ini adalah seluruh ibu hamil yang datang memeriksakan diri ke Puskesmas Wanakerta dan sampelnya adalah $124 \mathrm{ibu}$ hamil yang sudah mempunyai buku KIA, dan datang memeriksakan kehamilannya.

\section{HASIL DAN PEMBAHASAN}

Hasil penelitian menunjukkan bahwa 58,9\% ibu hamil telah memanfaatkan buku KIA dan 41,1\% tidak memanfaatkan Buku KIA.

Korespondensi penulis: nitahindayah@gmail.com 
Determinan Pemanfaatan Buku Kesehatan Ibu Dan Anak (Kia) ...

1. Tabel Distribusi karakteristik ibu hamil terhadap pemanfaatan buku KIA di Puskesmas Wanakerta Tahun 20015

\begin{tabular}{|c|c|c|}
\hline VARIABEL & $\begin{array}{c}\text { Frek } \\
\text { uensi }\end{array}$ & $\begin{array}{l}\text { Perse } \\
\text { ntase } \\
100 \%\end{array}$ \\
\hline \multicolumn{3}{|l|}{ Umur } \\
\hline$<20$ tahun $->35$ tahun & 16 & 12,9 \\
\hline 20 tahun -35 tahun & 108 & 87,1 \\
\hline \multicolumn{3}{|l|}{ Tingkat pendidikan } \\
\hline Rendah (SD, SMP) & 21 & 16,9 \\
\hline Tinggi (SMA, PT) & 103 & 83,1 \\
\hline \multicolumn{3}{|l|}{ Pengetahuan } \\
\hline Rendah & 26 & 21,0 \\
\hline Tinggi & 98 & 79,0 \\
\hline \multicolumn{3}{|l|}{ Sikap } \\
\hline Negatif & 21 & 16,9 \\
\hline Positif & 103 & 83,1 \\
\hline \multicolumn{3}{|l|}{ Paritas } \\
\hline Primigravida & 56 & 45,2 \\
\hline Multigravida & 68 & 54,8 \\
\hline \multicolumn{3}{|l|}{ Sosial Ekonomi } \\
\hline Rendah & 87 & 70,2 \\
\hline Tinggi & 37 & 29,8 \\
\hline \multicolumn{3}{|c|}{ Dukungan Tenaga Kesehatan } \\
\hline Rendah & 29 & 23,4 \\
\hline Tinggi & 95 & 76,6 \\
\hline \multicolumn{3}{|l|}{ Peran kader kesehatan } \\
\hline Rendah & 32 & 25,8 \\
\hline Tinggi & 92 & 74,2 \\
\hline \multicolumn{3}{|l|}{ Dukungan keluarga } \\
\hline Rendah & 51 & 41,1 \\
\hline Tinggi & 73 & 58,9 \\
\hline
\end{tabular}

Usia responden lebih banyak pada kategori usia 20-35 tahun, yaitu 108 orang $(87,1 \%)$, sedangkan usia $<20$ dan $>35$ tahun berjumlah 16 orang (12,9\%). Dari hasil ini diperoleh usia minimal responden yaitu 16 tahun, dan usia maksimal yaitu 40 tahun, dengan usia rata-rata yaitu 26 tahun. Berdasarkan distribusi pendidikan responden, mayoritas responden berpendidikan tinggi (SMA-PT) sebanyak 103 orang $(83,1 \%)$ sedangkan responden dengan pendidikan SD-SMP adalah sebanyak 21 orang (16,9\%). Berdasarkan distribusi pengetahuan responden, mayoritas responden mempunyai pengetahuan tinggi yaitu sebanyak 98 orang $(79,0 \%)$, sedangkan responden berpengetahuan rendah adalah 26 orang $(21 \%)$.

Berdasarkan distribusi sikap responden, mayoritas responden bersikap positif sebanyak 103 orang $(83,1 \%)$ dan responden yang bersikap negatif adalah sebanyak 21 orang $(16,9)$. Berdasarkan distribusi paritas, 68 responden merupakan multigravida dan 56 responden merupakan primigravida. Berdasarkan dukungan keluarga, sebanyak 73 orang $(58,9 \%)$ mendapatkan dukungan tinggi dan 51 orang $(41,1)$ mendapatkan dukungan rendah dari keluarga. 
The Southeast Asian Journal of Midwifery Vol. 2, No.1, Oktober 2016, Hal: 33-41

2. Tabel Distribusi Ibu hamil menurut karakteristik ibu, dukungan tenaga kesehatan, dukungan keluarga dukungan kader dan pemanfaatan buku KIA di Puskesmas Wanakerta, Karawang tahun 2015

pendidikan tinggi memiliki peluang 3,56

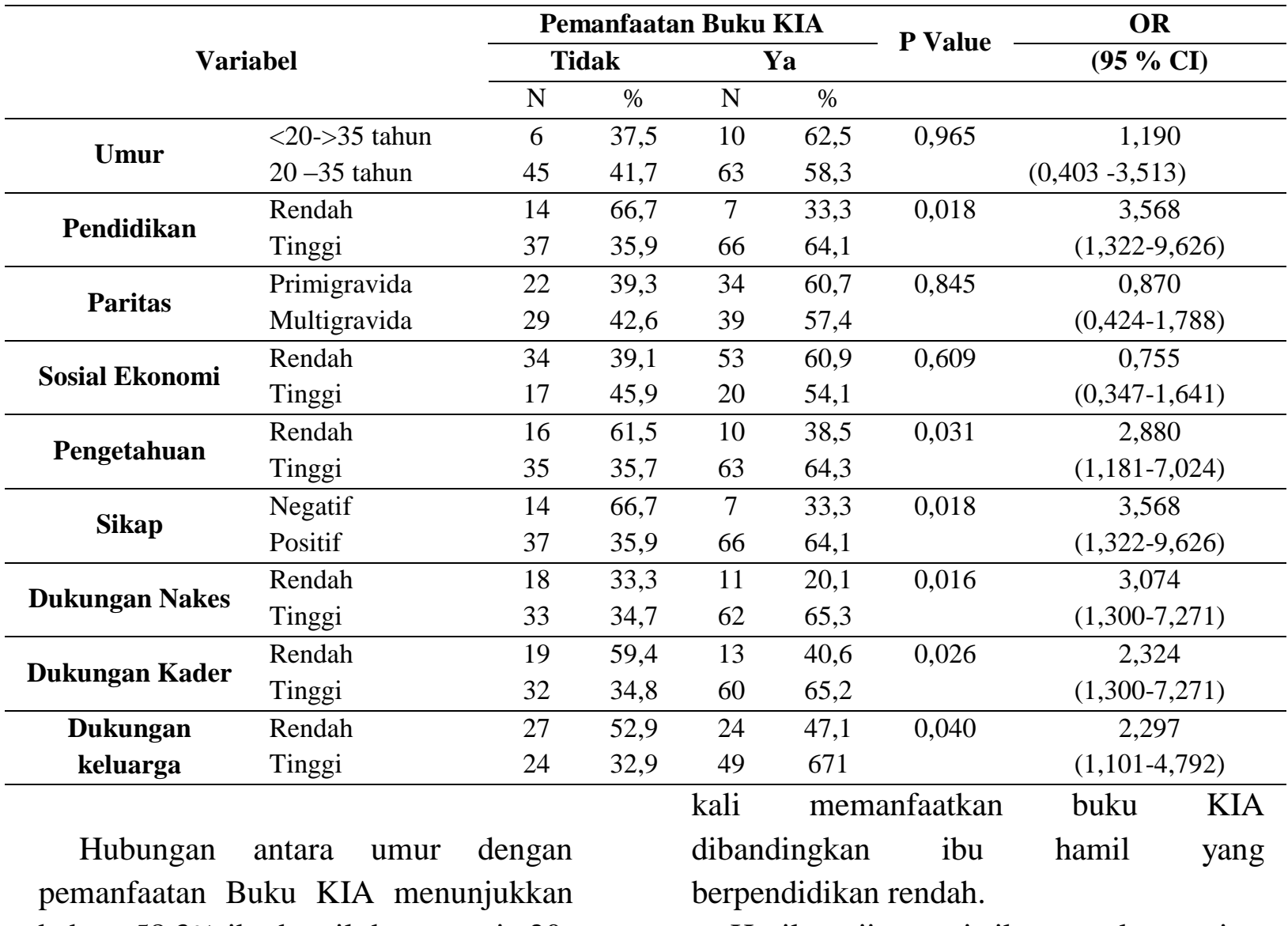

bahwa 58,3\% ibu hamil dengan usia 2035 dan $62,5 \%$ usia $<20->35$ tahun memanfaatkan buku KIA. Hasil uji statistik diperoleh nilai $\mathrm{p}=0,965$, yang artinya bahwa tidak ada hubungan antara umur dengan perilaku pemanfaatan buku KIA.

Pendidikan dengan pemanfaatan Buku KIA menunjukkan bahwa sebanyak 64,1\% berpendidikan tinggi. Hasil uji statistik diperoleh nilai $\mathrm{p}=0,018$ sehingga terdapat hubungan antara pendidikan dengan perilaku pemanfaatan buku KIA. Nilai $\mathrm{OR}=3,56$ berarti bahwa ibu hamil dengan
Hasil uji statistik untuk paritas diperoleh nilai $\mathrm{p}=0,845$, yang berarti bahwa tidak ada hubungan antara paritas dengan perilaku pemanfaatan buku KIA. Hasil uji statistik untuk pendapatan diperoleh nilai $\mathrm{p}=0,609$, yang berarti bahwa tidak terdapat hubungan antara sosial ekonomi ibu hamil dengan perilaku pemanfaatan buku KIA.

Sebanyak 64,3\% ibu hamil yang mempunyai pengetahuan tinggi memanfaatkan buku KIA. Hasil uji statistik diperoleh nilai $\mathrm{p}=0,031$ dan nilai $\mathrm{OR}=2,88$, yang artinya bahwa ibu hamil dengan pengetahuan tinggi memiliki 
peluang 2,88 kali untuk memanfaatkan buku KIA dibandingkan ibu hamil dengan pengetahuan rendah.

Sikap dengan pemanfaatan Buku KIA menunjukkan bahwa sebanyak $64,1 \%$ ibu hamil mempunyai sikap positif. Hasil uji statistik diperoleh nilai $p=0,018$, sehingga terdapat hubungan antara sikap dengan perilaku pemanfaatan buku KIA. Nilai $\mathrm{OR}=3,56$ berarti bahwa ibu hamil yang bersikap positif memiliki peluang 3,56 kali memanfaatkan buku KIA dibandingkan ibu hamil yang bersikap negatif.

Sebanyak 65,3\% ibu hamil mendapatkan dukungan tinggi dari tenaga kesehatan terhadap pemanfaatan buku KIA. Nilai $\mathrm{p}=$ 0,016 berarti bahwa terdapat hubungan antara dukungan dari tenaga kesehatan dengan perilaku pemanfaatan buku KIA. Hasil analisis nilai $\mathrm{OR}=3,07$ berarti bahwa ibu hamil yang mendapatkan dukungan tinggi dari tenaga kesehatan memiliki peluang 3,07 kali memanfaatkan buku KIA.

Sebanyak $65,2 \%$ ibu hamil mendapatkan dukungan tinggi dari kader kesehatan terhadap pemanfaatan buku KIA dengan nilai $p=0,026$, yang berarti bahwa terdapat hubungan antara dukungan dari kader kesehatan dengan perilaku pemanfaatan buku KIA. Nilai $\mathrm{OR}=2,32$ berarti bahwa ibu hamil yang mendapatkan dukungan tinggi dari kader kesehatan memiliki peluang 2,32 kali untuk memanfaatkan buku KIA.

Sebanyak $67,1 \%$ ibu hamil mendapatkan dukungan tinggi dari keluarga terhadap pemanfaatan buku KIA. Hasil uji statistik menunjukkan nilai $\mathrm{p}=0,040$, yang berarti bahwa terdapat hubungan antara dukungan dari keluarga dengan perilaku pemanfaatan buku KIA. Dari hasil analisis, nilai OR yang diperoleh adalah 2,29, yang artinya bahwa ibu hamil yang mendapatkan dukungan tinggi dari keluarga memiliki peluang 2,29 kali untuk memanfaatkan buku KIA dibandingkan ibu hamil yang mendapatkan dukungan rendah keluarga.

3. Tabel Model akhir Analisis Multivariat Regresi Logistik Ganda

\begin{tabular}{|c|c|c|c|c|c|c|}
\hline \multirow{2}{*}{ Variabel } & \multirow{2}{*}{ SE } & \multirow{2}{*}{ Wald } & \multirow{2}{*}{ Sig } & \multirow{2}{*}{ OR } & \multicolumn{2}{|c|}{ 95\% C.I for OR } \\
\hline & & & & & Lower & Upper \\
\hline Dukungan Keluarga & 0.842 & 4.685 & 0.030 & 2.320 & 1,083 & $\mathbf{4 , 9 7 2}$ \\
\hline $\begin{array}{l}\text { Pengetahuan } \\
\text { Sikan }\end{array}$ & 0,676 & 0,407 & 0,524 & 1,539 & 0,409 & 5,786 \\
\hline SIKap & 0,867 & 0,243 & 0,622 & 1,533 & 0,280 & 8,378 \\
\hline & 0,695 & 0,702 & 0,402 & 1,791 & 0,458 & 7,000 \\
\hline
\end{tabular}

Variabel yang berhubungan adalah Dukungan Keluarga dengan $\mathrm{p}$ value 0,030 dan OR 2,320 setelah dikontrol oleh variabel dukungan nakes, sikap, dan pengetahuan.
Variabel pengetahuan, sikap dan dukungan tenaga kesehatan adalah confounding variables 


\section{PEMBAHASAN}

Salah satu tujuan Program Kesehatan Ibu dan Anak (KIA) adalah meningkatkan kemandirian keluarga dalam memelihara kesehatan ibu dan anak. Dalam keluarga, ibu dan anak merupakan kelompok yang paling rentan terhadap berbagai masalah kesehatan seperti kesakitan dan gangguan gizi yang seringkali berakhir dengan kecacatan atau kematian (Depkes RI dan JICA, 2009) Untuk mewujudkan kemandirian keluarga dalam memelihara kesehatan ibu dan anak, salah satu upaya program adalah meningkatkan pengetahuan dan keterampilan keluarga melalui penggunaan Buku Kesehatan Ibu dan Anak (Buku KIA). Dari 124 responden, sebagian besar responden telah memanfaatkan Buku Kesehatan Ibu dan Anak (58,9\%). Hasil penelitian ini sesuai dengan hasil penelitian sistriani (2014) dengan sebagian besar responden $(52 \%)$ yang memiliki kualitas baik dalam penggunaan buku KIA. Hal ini dilihat dari kepatuhan ibu membawa buku KIA serta kelengkapan isi buku KIA.

Madris dalam Wanda (1998) menyatakan bahwa usia merupakan aspek demografis yang penting untuk diamati. Usia dianggap penting karena dapat mencerminkan beberapa nilai seperti pengalaman, pengetahuan, kematangan berpikir dan kemampuan akan beberapa nilai tertentu.

Pendidikan seseorang mempengaruhi cara berfikir dalam menghadapi pekerjaan. De Partie Santis (1996) dikutip oleh Laurenta (2001) membuktikan bahwa pendidikan adalah salah satu faktor yang mempengaruhi pendapatan dan cara kerja seseorang. Sebanyak $83,1 \%$ ibu hamil sudah memiliki pendidikan tinggi dan $16,9 \%$ mempunyai pendidikan rendah.
Proporsi ibu dengan paritas yang memanfaatkan buku KIA berbeda sedikit, yaitu $60,7 \%$ lebih dengan paritas primigravida dan $57,4 \%$ pada paritas multigravida. Dalam penelitian ini, ibu hamil dengan paritas primigravida mungkin sedang berusaha memahami betul fungsi dan manfaat dari buku KIA, karena bila ibu hamil tersebut yakin terhadap manfaat dari buku KIA maka, dia akan memilih untuk selalu membawa buku tersebut ketika pemeriksaan, berusaha membaca dan memahami isi bukunya dan selalu menjaganya.

Proporsinya ibu hamil yang lebih banyak memanfaatkan buku KIA adalah ibu hamil dengan pendapatan keluarga yang rendah sebesar $72,6 \%$ sedangkan ibu hamil dengan pendapatan keluarga yang tinggi adalah sebesar 27,4\%. Hasil ini berbeda dengan penelitian Sistriani (2012) yang menyatakan bahwa catatan buku KIA lengkap lebih banyak didapatkan pada ibu dengan tingkat ekonomi tinggi sedangkan ibu dengan tingkat ekonomi rendah cenderung jarang memanfaatkan layanan posyandu. Ibu yang mempunyai tingkat ekonomi tinggi merupakan ibu bekerja yang juga tergolong mempunyai tingkat pendidikan menengah.

Hasil penelitian menunjukkan bahwa ibu hamil dengan pengetahuan tinggi yang telah memanfaatkan buku KIA adalah sebesar 86,3\% dan pengetahuan rendah adalah sebesar $13,7 \%$. Dari pertanyaan yang diajukan ke ibu hamil didapatkan bahwa 96,7\% ibu hamil sudah mengetahui dengan baik bahwa buku KIA adalah buku kesehatan ibu dan anak. Hasil uji statistik diperoleh nilai $p$ value 0,031 sehingga ada hubungan antara pengetahuan dengan perilaku pemanfaatan buku KIA. Hasil penelitian ini sejalan dengan Sistriani (2014) dengan ibu yang pengetahuan tinggi lebih besar sebanyak $56 \%$ dibandingkan 
dengan pengetahuan yang rendah sebanyak $44 \%$.

Sebanyak $85,2 \%$ ibu hamil menyatakan bahwa buku KIA perlu didiskusikan dengan petugas kesehatan dan keluarga. Hasil uji statistik memperoleh nilai $p$ value 0,018 sehingga terdapat perbedaan yang signifikan pada proporsi antara ibu hamil yang bersikap positif dan ibu hamil dengan sikap negatif terhadap perilaku pemanfaatan buku KIA. Oleh karena itu, sikap mempunyai hubungan dengan perilaku pemanfaatan buku KIA. Hasil ini sejalan dengan penelitian yang dilakukan Fatimah dkk (2009) yang menyatakan bahwa sikap ibu hamil mendukung pemanfaatan buku KIA.

Hasil analisis berdasarkan nilai OR tentang ibu hamil yang mendapat dukungan dari petugas kesehatan menunjukkan bahwa dukungan petugas akan mendorong ibu untuk memanfaatkan buku KIA sebesar 2,522 kali dbandingkan dengan ibu hamil yang tidak mendapat dorongan dari petugas kesehatan. Hal ini membuktikan bahwa dukungan petugas adalah sangat penting dalam keberhasilan ibu untuk memanfaatkan buku KIA. Buku KIA merupakan buku wajib untuk dibaca oleh ibu hamil dan keluarga karena berisi informasi penting dan berguna bagi kesehatan ibu dan anak. Penggunaan buku KIA secara baik tidak terlepas dari penyuluhan oleh bidan dan tenaga kesehatan lain pada setiap kunjungan ibu hamil.

\section{KESIMPULAN}

Variabel yang berhubungan dengan pemanfaatan buku KIA dalam penelitian ini adalah pendidikan, pendidikan, sikap, dukungan tenaga kesehatan, dukungan kader kesehatan, dan dukungan keluarga. Sementara itu, umur, paritas, dan sosial ekonomi tidak berhubungan dengan pemanfaatan buku KIA oleh ibu hamil.

\section{DAFTAR PUSTAKA}

Arikunto S. Prosedur penelitian, suatu pendekatan praktik, Jakarta: Rineka Cipta; 2010 h,203; 279

Azwar, S 1995. Sikap manusia, teori dan pengukurannya, Yogjakarta, pustaka pelajar.

Bhulyan SU, Nakamura Y, Qureshi NA, Studi On development And Assesment Of Maternal and Child Health (MCH) Handbook in Bangladesh. Journal of public Health and Development, 2006 ; 4(2) : 45-60

Colti S dan Elviera G. 2012. Analisis Pencapaian Indikator KIA di Puskesmas Kalibangor. Jurnal Kesmas Indonesia, 4(6) : 120-95

Colti Sistriani, Elviera Gamelia, Dyah Umiyarni Purnama Sari, 2012 Fungsi Pemanfaatan Buku KIA terhadap Pengetahuan Kesehatan Ibu dan Anak Pada Ibu. Artikel penelitian Unsoed hal 353-356

Colti Sistriani, Elviera Gamelia, Bambang Hariyadi 2014. Analisis Kuallitas Penggunaan Buku Kesehatan Ibu Anak. Jurnal Kesehatan. Kemas 10 (1) (2014) 14-20.

Departemen Kesehatan Republik Indonesia. Buku Kesehatan Ibu dan Anak dan JICA. Jakarta ; Depkes RI; 2009. H1-64

Departemen Kesehatan Republik Indonesia. Pedoman Umum manajemen Penerapan Buku KIA. Jakarta : Departemen Kesehatan Republik Indonesia : 2010

Dinas Kesehatan Kabupaten Karawang. Profil Kesehatan Kabupaten Karawang Tahun 2014

Dinas Kesehatan Provinsi Jawa Barat. Profil Kesehatan Provinsi Jawa Barat Tahun 2013

Dora D, Faktor-faktor yang berhubungan dengan tingkat pemahaman ibu hamil terhadap pesan antenatal care yang terdapat didalam buku KIA (Tesis). Semarang Fakultas Kedokteran; 2010 
Ernoviana M.H, 2005. Pemanfaatan Buku Kesehatan Ibu dan Anak di Dinas Kesehatan Kota Sawahlunto (Edisi 2005)

Green, Health Education Palnning A Diagnostic Approach The Join Hopkins, 1980

Hagiwara, A; Ueyema, M; Ramlawi, A; Sawada' Y 2012. Is Maternal and Child Health (MCH) Handbook Effective In Improving Health Related Behaviour? Evidence From Palestine. Pubmed, 34 (1): $34-35$

Hasanbasri dan Ernoviana 2006. Pemanfaatan Buku Kesehatan Ibu dan Anak di Dinas Kesehatan Kota Sawahlunto. (Edisi 2006, Diakses tanggal 3 April 2014).

Heru AS, Kader kesehatan Masyarakat. Jakarta: EGC 2005

Hornby, A.S (2000). Oxford Adavanced

Learning's Dictionary of current English, $6^{\text {th }}$ ed.,Oxford University Press

Kementrian Kesehatan Republik Indonesia. Survei Demografi dan Kesehatan Indonesia Tahun 2012. Jakarta: Kementrian Kesehatan Republik Indonesia; 2012

Laksmono W, Besar Tahun 2006. Pemanfaatan Buku KIA oleh Kader Posyandu. Studi pada Kader Posyandu di wilayah kerja Puskesmas Kedung Adem Kabupaten Bojonegoro Jurnal Makara Kesehatan 2006; 13(1); 47-49

Laurenta, 2001 studi deskriftif dan analisis faktor yang berpengaruh dalam tingkat pengetahuan KIA pada ibu dan anak di Puskesmas Cakranegara Mataram. Jurnal Kesehatan Prima 2007.

Muhammad AM, Tety R. 2012. Peran Kader Kesehatan Dalam Program Perencanaan Persalinan dan Pencegahan Komplikasi pada Ibu hamil di Posyandu Di Kota Mojokerto, Provinsi Jawa Timur. Buletin Penelitian Sistem Kesehatan, 15 (4): 358360

Nadia, 2000, Hubungan antara kepemilikan buku KIA dengan pengetahuan, sikap, dan praktik perawatan kehamilan diwilayah kerja Puskesmas Rangkah Surabaya, Embrio Jurnal Kebidanan, 2012

Nakamura, Yasuhide, 2010. Maternal and Child Helath Handbook In Japan. JMAJ 53 (4): 259-265

Nasril (2000). Faktor - faktor Yang Berhubungan Dengan Kepatuhan Ibu Hamil Membawa " Buku KIA" Di Wilayah Kerja Puskesmas Padang Sago Kabupaten Padang Pariaman Tahun 2000, Depok.

Notoatmodjo Soekidjo (2007), Promosi Kesehatan dan Ilmu Perilaku, Jakarta Rineka Cipta : Hal 178

Notoatmodjo Soekidjo (2010), Metodologi Penelitian Kesehatan, Jakarta Rineka Cipta : Hal 178

Osaki K, Hattori T, Kosen S, Singgih B. Investment In Home-Based Maternal, NewBorn and Child Health Record improves Immunization Coverage in Indonesia. Transaction of the Royal society of Toppical Medicine and Hygiene (Serial of internet).

Sabri L Dan Hastono S (2009). Statistik Kesehatan Jakarta: Rajawali Pers

Satoko Yanagisawa, Ayako Soyano, Hisato Igarashi, Midori Ura and Yasuhide Nakamura 2015. Effect of a Maternal and Child Health Handbook on Maternal Kowledge and Behaviour : a Communitybased Controlled trial in rural Cambodia. Health policy and planning 2015: 1-9

Widaningrum D, Wirawan, Hasanbasri M, Implementasi Buku Kesehatan Ibu dan Anak di Kabupaten Mimika, Рapua. Yogyakarta: Working Paper Series No. 16 April 2007, First Darft KMPK UGM

Widagdo L Dan Husodo (2009). Pemanfaatan Buku KIA Oleh Kader Posyandu : Studi pada kader Posyandu di Wilayah Kerja Puskesmas Kedungadem Kabupaten Bojonegoro, Semarang : Makara, Kesehatan Vol.13 No.1 Juni 2009 :39-47

Wirawan, Suparyono 2007. Hubungan Antara tingkat pengetahuan Ibu dan Efektifitas Buku KIA dengan Pengetahuan Ibu Balita di wilayah Puskesmas Cakranegara, Mataram. Jurnal kesehatan Prima 1:8493 
Nita Farida

Determinan Pemanfaatan Buku Kesehatan Ibu Dan Anak (Kia) ...

Zulkifli (2003). Posyandu dan Kader

Kesehatan digital Library FKM - USU 